PANTOJA, Selma. Nzinga Mbandi: mulher, guerra e escravidão. Brasília: Editora Thesaurus, 2000.

\title{
O UNIVERSO NEGRO-AFRICANO E SUAS PECULIARIDADES: A ESCRAVIDÃO, O TRÁFICO E O MITO DA RAINHA NZINGA. ${ }^{84}$
}

Mariana Ouriques ${ }^{85}$

Escrito pela historiadora Selma Pantoja, o livro Nzinga Mbandi: mulher, guerra e escravidão, aborda alguns elementos da história de Angola durante o século XVII. Com o prefácio de Alberto Costa e Silva, a obra mostra o mito da rainha Nzinga que ascendeu ao poder rompendo as normas estabelecidas pelas linhagens tradicionais, que não admitiam uma mulher no poder. Além de também, dentre outras questões, Selma Pantoja traz as especificidades da escravidão dentro do continente africano.

As peculiaridades da história da África Negra trouxeram desafios para a historiografia. Sobre as fontes escritas percebe-se uma visão estereotipada dos africanos e suas sociedades, são relatos feitos por viajantes europeus carregados de superioridade. Com uma população ágrafa temos a tradição dos testemunhos orais que necessitam de uma técnica especial.

A obra traz um extenso relato sobre as características do povo Mbundu, bem como as especificidades da escravidão africana que tanto difere da praticada nas Américas. Deixa claro que ela é muito mais antiga do que se pensa, que era imanente naquele continente, mas de nenhuma forma benévola. E permeando toda a obra está a presença de Nzinha Mbandi que bravamente lutou contra o domínio português no Ndongo.

Sobre a escravidão africana vale ressaltar algumas características relativas à ela como o sistema de parentesco, os direitos pessoais, o escravo como propriedade, e este como sendo um dos tipos de dependência.

A autora também destaca a importância da mulher na sociedade africana, onde ela é o principal trabalhador agrícola e está diretamente ligada a produção e reprodução.

Selma Pantoja diz não ser adequado identificar a escravidão a partir do atributo propriedade, pois justifica que seus direitos são negociáveis, que tanto pessoas livres como escravos poderiam se negociados como propriedade.

Nota-se como característica marcante dos escravos africanos a ausência de parentesco, a nãointegração com a linhagem ou etnia local. Para tanto era necessário que este indivíduo fosse retirado de local de origem, enfatizando sua procedência estrangeira. A guerra, o seqüestro, as razias eram as

84 Resenha apresentada à Disciplina de História da África, ministrada pela Professora Dra. Fabiane Popinigis na Universidade Federal de Santa Catarina-UFSC 
formas mais comuns de escravização e ao contrário que se imagina, aqui, o escravo não trabalhava somente em atividades produtivas, poderia este desempenhar cargos políticos e sociais.

E como o escravo está presente na estrutura econômica de uma sociedade africana? A autora mostra que, quando esta mesma sociedade depende do escravo, temos uma sociedade escravista. Porém a simples presença da escravidão e do escravo não necessariamente a define desta maneira.

Selma Pantoja dedica um capítulo de seu livro mostrando a organização e características da sociedade na África Central Ocidental. Primeiramente os povos de língua bantu onde há apenas uma breve amostra de características dessa sociedade, tais como prática da agricultura e da metalurgia, que possuíam um regime de descendência matrilinear, patrilinear e até de descendência dupla.

Após a autora enfatiza os povos coletores, existentes na África Central Ocidental, chamado de bosquímanos. Estes foram grupos nômades e tiveram sua população absorvida pelos povos de língua bantu, que resultou em um violento impacto no modo de vida dos povos caçadores.

Importante ressaltar que com a relevância da introdução do ferro na agricultura, facilitando na abertura de clareiras, que foi ideal para o cultivo de banana, tão importante na dieta bantu, fez com que o ferreiro tivesse muito prestigio dentro da sociedade, tornando-se o mais importante artesão da -aldeia.

Uma unidade política organizada em confederação de linhagem é mostrada como exemplo dentro da complexidade do sistema político da região, os Mbundu.

Uma característica marcante desta população eram os laços de parentesco além de muitos dependentes. Como no caso da mulher, que vivendo em uma sociedade polígama, tinha seu trabalho apropriado pelo homem.

A região do litoral da África Central criou estados que se apoiavam na autonomia de linhagem. Eles baseavam-se em uma relação social ou de parentesco consangüíneo, neste ultimo podendo ser matrilinear ou patrilinear. No caso dos Mbundu são predominantemente matrilineares, porém patriarcal, ou seja, segue-se a linhagem materna, mas sempre representado pelo homem.

Há um trecho onde podemos tornar a imagem de Angola mais real, com os aspectos geográficos da região. No que diz respeito às demarcações do domínio dos povos, estas eram feitas pelos rios e mares. O mar litorâneo era de domínio dos reis africanos, já o alto mar pertence aos europeus. 0 clima angolano é descrito como sendo intertropical, com o índice pluviométrico aumentando quando se afasta do litoral, já ao sul o climá é árido devido ao deserto.

Agora a autora adentra na história do Congo e do estado do Ndongo, onde viviam os Mbundu.

O Congo era divido entre cidades e a população das aldeias, sendó os títulos pertencentes aos habitantes das cidades. Quanto à religião houve um processo de cristianização que se operou somente à elite congolesa.

O governo central era mantido pela cobrança de impostos, estes eram pagos com tecidos, marfim ou cativos. 
Uma expedição vinda de Portugal vinda de Portugal, em 1482, estabeleceu contato com o Congo, com interesses comerciais, os lusos introduziram na costa africana o comércio de manufaturas. No início esta relação luso-bakongo era amistosa, até a cristianização ter sido posta de lado pelo interesse no comércio de escravos.

O escravo era utilizado como pagamento no estudo dos africanos em Portugal. Sua venda rendia também impostos para o Manikongo, chefe do Congo. Em 1512 este comércio tornou-se monopólio real.

Durante o século XVII o Congo foi invadido pelo grupo dos yagas, que foi na verdade um golpe para os chefes locais, os Manikongos e comerciantes portugueses, estes guerreiros lutaram ao lado dos Mbundu. Foi então que resultou na hegemonia do Ndongo na região.

Os Mbundu era inicialmente organizado em forma de aldeia constituído por grupos de filiação. Os membros destes grupos tinham o controle das terras para o seu cultivo.

Sobre o soberano, era chamado de Ngola, este passava por um ritual relacionado à posse de objetos considerados sagrados.

Toda a população, aparentemente, estava submetido ao Ngola, mas havia diferença na forma de submissão, dentre as mais comuns formas de dependência estavam os prisioneiros de guerra, escravos por dívidas ou por punição de algum crime, estes não estavam inseridos em nenhum sistema de parentesco. Eram os cativos e as mulheres que se dedicavam à produção agrícola.

E é neste contexto que surge a figura de Nzinga Mbandi, e foi durante seu governo que o Ndongo sofreu sua fase mais tensa, a luta contra os lusos no comércio de escravos e o ataque dos Mbangalas. Nzinga destaca-se por conseguir equilibrar-se neste período de crise no governo.

Nota-se que o mito da rainha Nzinga também serve para autora enfatizar por várias vezes a importância da mulher na sociedade africana, tanto no poder como o principal produtor agrícola.

Voltando ao assunto do contato Portugal-África, foi em 1540 que os lusos tiveram contato com os soberanos Mbundu, e foram estes que buscaram contato com os europeus. O Ngola pediu aos portugueses que enviassem ao Ndongo padres e comerciantes. Mas quando o capitão Novais, enviado pelo reino português, chegou a região e o novo Ngola não quis recebê-lo e após alguns meses de espera o capitão avançou para o interior. O Ngola não apenas se recusou a ser convertido ao cristianismo, como prendeu Novais juntamente com o padre Gouveia.

Para incrementar o comércio de escravos os portugueses combateram contra os Mbundu ao longo do século XVII, e esta tarefa foi difícil pois os portugueses encontraram a resistência de Nzinga Mbandi.

Os portugueses usavam diversos pretextos para iniciar uma campanha militar com intuito de capturar mais escravos. Mas sem o apoio dos africanos os portugueses não poderiam ter acesso às rotas de comércio. A resistência de Nzinga vai dificultar todo comércio de escravos por todo século XVII.

Com a morte de Ngola Mbandi em 1617, houve uma disputa pelo poder entre Kia Mbandi e 
Nzinga. Ela fugiu para Matamba, onde não poderia mais reivindicar o título, já que para as linhagens tradicionais não aceitavam uma mulher no poder.

Seu irmão teve um governo marcado por inúmeras guerras, devastando o Ndongo. O governador empreendeu uma campanha militar contra o Ndongo e acabou que com sua capital destruída.

Para que a paz fosse restabelecida precisou de alguém com habilidade de negociação, Nzinga, uma mulher com capacidades não só diplomáticas como de guerra como demonstrou dentro de seus quilombos.

O Ngola Mbandi entra em contato com sua irmã Nzinga, que desempenha as negociações entre Ndongo e Portugal na negociação de paz entre os dois estados. Durante a década de 20 os portugueses conseguiram estabelecer aliança no.Ndongo. O Ngola Mbandi falece e Nzinga detentora das insignias reais apodera-se do poder.

Os dois últimos capítulos são onde Nzinga Mbandi está mais presente na obra de Selma Pantoja.

Nzinga adotou os costumes dos Mbangalas, e não aceitou a proposta dos portugueses para que o Ndongo tornassem seus tributários. Ela pediu em carta à Portugal, que enviassem padres ao Ndongo e em troca devolveria os escravos que haviam fugido dos portugueses e refugiaram-se no quilombo.

Porém os portugueses expulsaram Nzinga e colocaram um chefe submisso aos interesses lusos, Aire Kiluanji, que abriu as rotas comerciais do Ndongo. Os chefes Mbundu não reconheciam o Ngola, por ele não pertencer à linhagem. O que permeava esta resistência era o sentimento anti-português da região.

Após um assalto à ilha de Kwanza empreendido pelo governador, Nzinga foge para Matamba e ela passa a adotar os costumes e as formas militares dos Mbangalas.

O confronto militar do Ndongo com os portugueses resultou na demolição das bases do estado, além da propagação da varíola que despovoou aldeias inteiras.

É sempre recorrente falar em escravos que eram acolhidos pela Nzinga e este fato servia de argumentação para justificar a guerra contra a rainha Mbundu. Nzinga era soberana no Matamba, rompeu com as regras estabelecidas, sendo uma mulher no poder usando de força-militar para consegui-lo.

Em 1641, Nzinga apóia a ocupação de Luanda pelos holandeses, o qual deseja seu apoio político. Nzinga usou a presença dos holandeses para expulsar de vez os portugueses e reaver o Ndongo. Os portugueses foram reduzidos à posição de intermediários ao comércio de escravos. Em 1648 os holandeses unidos a Nzinga avançaram contra os portugueses.

Os maiores rivais dos portugueses passaram a ser Matamba e o Congo. Foi durante o governo de Vidal de Negreiros que ocorreu o golpe fatal ao Congo deixando-o enfraquecido, mas este continuaria existindo até o século XIX.

Sobre Matamba, foi assinado um acordo de paz com os portugueses, para tal os lusos teriam 
que libertar a irmã de Nzinga e ela comprometia-se em entregar alguns escravos. A rainha Nzinga se e converteu ao cristianismo e aceitou a presença dos missionários na região. Neste momento era impossível lutar mais contra os portugueses, pois não havia possibilidade de reorganizar um exercito no Ndongo, já despovoado.

Foi durante o século XIX que a África tornou-se mais vulnerável as invasões européias, pois antes a malária era uma espécie de barreira natural, e neste século foi descoberto o quinino, que ajudou os portugueses a driblar esta barreira.

Nzinga faleceu em 1663 , ela foi temida por não só ter sobrevivido a varíola como por ter adotado os ritos Mbangalas.

As conseqüências da disputa pelo comércio de escravos foram grandes, como a redução da população local, o aumento do numero de cativos, a redução da população local e a escravização de pessoas livres.

O Ndongo foi o principal fornecedor de escravos para Luanda, em um momento em que tive uma relação estreita com o comercio atlântica durante o século XVII.

Segundo Cavazzi, na região do Ndongo existiam três tipos de escravos: os quísicos, que eram filhos de outros escravos; os prisioneiros de guerra, que poderiam ser usados em sacrifício; e os escravos de fogo, que viviam em perpetuo serviço até a morte de seu proprietário.

Aos escravos eram negados direitos e privilégios, diferenciados dos demais membros da sociedade devido à ausência de parentesco. Tanto os escravos como as mulheres estavam subordinados aos mais velhos da linhagem.

Foi por meio do apoio destes escravos que Nzinga Mbandi conseguiu subir ao poder no Ndongo e tornar-se um mito não só no continente africano, mas para todos os afrodescendentes. 